\title{
Guidelines on Safe Work Practice when Commuting in Oil Palm Plantations
}

\author{
Akmal Wani Sulong, Azmi Hassan, Tengku Mohamed Ariff Raja Husin
}

\begin{abstract}
Previous local researches on the oil palm workers are mostly focusing on the musculoskeletal disorders and ergonomic issues. However, the workers are easily exposed to many other accidents such as commuting accidents. The location of the oil palm plantations itself which are remote and requires the workers to commute far from their home elevate the possibility of commuting accidents. The present paper describes contributing factors to commuting accidents and suggests guidelines to be followed as prevention from such accidents. Reports, news, and previous research on commuting accidents are reviewed and cross-referred with the safety and health guidelines in the agriculture published by the International Labour Organization (ILO) and Department of Occupational Safety and Health (DOSH) Malaysia to ensure it fits the commuting nature in an oil palm plantation. A safety and health practice guideline is presented in this paper, still, regular training and commitment from both the organisation and the workers are essential in ensuring the safety of the workers.
\end{abstract}

Index Terms:- Commuting accidents, guidelines, oil palm plantation, safety and health..

\section{INTRODUCTION}

The agriculture industry has been the backbone to the Malaysian economy for many years due to its high contribution to the Gross Domestic Product (GDP). As of recently, the industry contributed $8.1 \%$ to the GDP which equivalent to RM 89.33 billion in 2016 [1]. The largest contributor to the agriculture sector was the oil palm subsector with $43.1 \%$, followed by food crops (17.8\%) and the livestock (11.7\%) [2]. The significance of the subsector can be observed through 5,811,145 hectares of land in Malaysia which dedicated for the oil palm plantations [3]. Accordingly, thousands of labours are working in the subsector to keep up with the productivity demands. Due to its labour-intensive working nature, the oil palm workers are easily exposed to various occupational accidents, diseases, and injuries. Previous studies in Malaysia have found that the most significant injuries among the oil palm workers were the musculoskeletal disorders consisting of pains and discomfort at lower back, shoulder, neck, knee, and ankle [4]-[8]. A recent pilot study has also found that other accidents and injuries were also frequent and the underreporting among the workers were worrying [9]. Even so, there is another occupational accident which is overlooked in this field; the commuting accident.

Commuting accident not only caused fatality or injuries, but would also affect the cost of compensation, loss of workdays, loss of talents, and reduce an organisation's

Revised Manuscript Received on July 10, 2019

Akmal Wani Sulong Institute of Community (Health) Development, Universiti Sultan Zainal Abidin, Terengganu, Malaysia.

Azmi Hassan, Faculty of Medicine, Universiti Sultan Zainal Abidin, Terengganu, Malaysia.

Tengku Mohamed Ariff Raja Husin, Faculty of Medicine, Universiti Sultan Zainal Abidin, Terengganu, Malaysia. productivity [10]. Concerned with the importance of safe commuting, several Malaysian agencies have developed their guidelines to improve this issue. In addition, the International Labour Organization (ILO) and the Department of Occupational Safety and Health (DOSH) Malaysia have also published guidelines on safety and health in agriculture as references to tackle this problem. Nevertheless, the frequency of commuting accident in the oil palm industry translates that these guidelines have failed to either be followed or enforced in the organisation. In the inspection report of fatal cases in the oil palm plantations from 2010 until recently, six out of thirteen cases were the commuting accidents [11].

This paper reviewed previous studies on commuting accidents in other sectors as the reference to identify the potential contributing factors to the commuting accidents in the oil palm plantations. In order to improve the enforcement of the safe work practice when commuting in the oil palm plantation, we proposed a simplified guideline based on the original agriculture guidelines provided by ILO and DOSH. The initiative to propose this guideline arises from the interest of smaller organisation which may have issues to afford a safety management system.

\section{MATERIALS AND METHODS}

\section{A. Literature Search}

The selected literature for review in this study should cover the commuting accidents which are work-related, discussed the contributing factors, as well as prevention ideas. These studies were identified by searching in two electronic libraries namely the Web of Science (WOS) and Google Scholar. These two databases were chosen because they cover many different libraries. Similar keywords or key phrases were used during the search and the publications were limited from the year 2013 until recently.

The keywords or key phrases that were used in our study were "work-related" OR "occupational" AND "commuting accidents", and they initially resulted in a total of 437 results from both databases. The search for only English results then caused in a total of 364 papers to be reviewed. These results were then checked for duplicates before review of the abstracts were done. Consequently, only 17 relevant papers that were identified from the abstract reviews used for full review. We then include the guidelines on safety and health

in agriculture by ILO and DOSH as well as an inspection report by DOSH to complement our reviews on the contributing factors. 
The literature search process is shown in the following Fig. 1.

\section{B. Inclusion and Exclusion Criteria}

During the selection phase, we only selected those publications which were relevant to our objective and removed others from our search results. We screened the results using our inclusion and exclusion criteria to end up with our primary studies. The inclusion criteria used for our study included (a) papers that were written in English, (b) papers that were available online, (c) papers that were discussing safe commuting or the contributing factors to commuting accidents, (d) papers that were published from January 2013 until recently, and (e) the study is a scientific publication. Therefore, other publications that were (a) written in other languages than English, (b) not accessible online, (c) unrelated to our study, (d) published before January 2013, and (e) not scientific publications, were all removed from the search results.

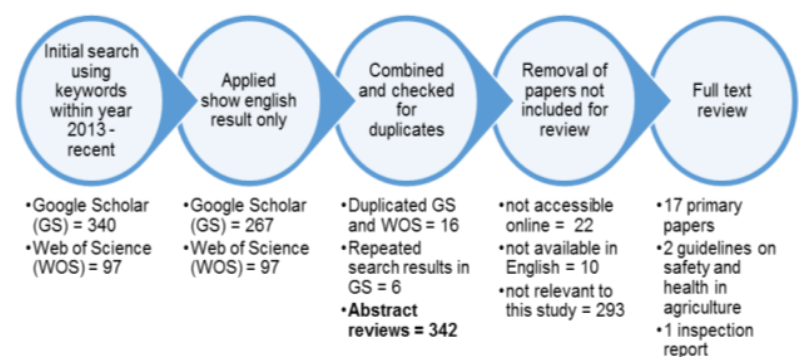

Fig. 1: Literature selection process for this study

\section{Development of Proposed Guidelines}

We referred to the general guidelines on safety and health in agriculture published by ILO and DOSH in developing our safe work practice for commuting in oil palm plantations. These guidelines were widely used in the agriculture industry because it covers different types of farm ranges. Though the guidelines are generally helpful for safe work practice, the descriptions are lengthy and preferable for management level. Hence, we summarised the guidelines based on the contributing factors to commuting accident and simplified the sentences to ensure the suitability of the guidelines for all workers. Since not all contributing factors were retrieved from the oil palm plantation perspective, we developed the guidelines with consideration of the commuting situation in the oil palm plantations.

\section{RESULTS \& DISCUSSIONS}

\section{A. Commuting Accidents in the Oil Palm Plantations}

An accident is an unexpected and unplanned event which may or may not cause injuries or losses either to human beings, a place, or belongings [12]. Meanwhile, a workrelated commuting accident is an accident which happens in employment, during commuting from home to a workplace or commuting home from the workplace, while travelling for work purposes, and while travelling for authorised recess [13]-[15].

In the oil palm plantations, commuting activities include transporting human and transporting cargo or loading. These activities can be observed during travelling to work in the morning, travelling after the work finishes, site visit by the supervisor or employer, travelling into the plantation to pick up fresh fruit bunches (FFB), transportation of FFB from the plantation area to the oil palm mills, and transportation of chemicals, equipment, tools, and machinery. These commutes use different types of vehicles, for example, motorcycles, tractors, and lorries, therefore the risks of each commute vary. Subsequently, the guideline for the safe work practice when commuting in the oil palm plantations shall consider this matter.

Based on the report retrieved from DOSH's official website on 4 November 2018, six out of thirteen fatal cases in the oil palm plantations from March 2010 until September 2018 were commuting accidents. According to their observation, the accidents were caused by the failure of the employer to provide safe access, no safe work procedures, and lack of supervisions [11]. In recent news, a foreign worker died when the tractor she was travelling skidded and fell down a ravine due to uneven road condition. In general, the location and surroundings of the oil palm plantations which are remote, vast, bushy, and hilly are all risky to the oil palm workers and visitors.

\section{B. Contributing Factors to Commuting Accidents}

Six contributing factors to the commuting accidents were identified from our literature review. The factors are the health of driver, behaviour of driver, environment, vehicles, the commitment of the employer on safety issues, and training. The elements that signify these six factors are described more on the following Table 1.

Table 1: Contributing factors based on references

\begin{tabular}{|c|c|}
\hline Contributing Factors & References \\
\hline \multicolumn{2}{|l|}{ Health of driver } \\
\hline Diabetes & {$[16]$} \\
\hline Degenerative eye condition & [17] \\
\hline Younger age (less than 30 years old) & [18], [19] \\
\hline Cognitive failure or forgetfulness & {$[20]$} \\
\hline Frequent or recently having MRI scan & [21], [22] \\
\hline Sleep quality & [23] \\
\hline \multicolumn{2}{|l|}{ Detachment from work } \\
\hline Fatigue / overwork & {$[10],[24]-[26]$} \\
\hline Drug / alcohol use & [26]-[28] \\
\hline \multicolumn{2}{|l|}{ Behaviour of driver } \\
\hline Rushing / speeding & {$[25],[26],[29]$} \\
\hline Break traffic rules & {$[30]$} \\
\hline Illegally loading over limit & [24] \\
\hline Poor focus / texting while driving & [25] \\
\hline \multicolumn{2}{|l|}{ Vehicles } \\
\hline Poorly maintained & [26], [29] \\
\hline Poorly visible & [31], [29] \\
\hline Misused & [29] \\
\hline Environment & \\
\hline
\end{tabular}

Poor road condition (poorly
maintained)
$\begin{aligned} & \text { Published By: } \\ & \text { Blue Eyes Intelligence Engineering } \\ & \text { \& Sciences Publication }\end{aligned}$
Exploring Innovation




\begin{tabular}{|l|c|}
\hline Uneven road / hilly and slopes & {$[30],[26]$} \\
\hline Poor lighting & {$[32]$} \\
\hline Bad weather & {$[24],[10]$} \\
\hline \multicolumn{1}{|c|}{ Employers' commitment } & \\
\hline Housekeeping & {$[24]$} \\
\hline Maintenance of vehicles & {$[26]$} \\
\hline Safe access & {$[11]$} \\
\hline Warning sign & {$[29]$} \\
\hline Safe work procedures & {$[11]$} \\
\hline Traffic inspection & {$[27]$} \\
\hline \multicolumn{2}{|c|}{ Training } \\
\hline Drivers' training & {$[33]$} \\
\hline Driving license & {$[27]$} \\
\hline
\end{tabular}

C. Guidelines of Safe Work Practice When Commuting in the Oil Palm Plantations

We referred the guidelines on safety and health in agriculture which were published by ILO and DOSH in developing our guidelines for safe work practice when commuting in the oil palm plantations. Based on the abovementioned factors in Table 1, we referred to both guidelines on the types of risk, hazards, and prevention measures and summarised them. We used simplified sentences to make sure the guidelines can be referred by all workers in all size of an organisation. The proposed guidelines are explained in the following Table 2 .

Table 2: Proposed safe work practice when commuting in the oil palm plantations based on ILO and DOSH guidelines

\begin{tabular}{|c|ll}
\hline Item of Guidelines & & Safe Work Practice \\
\hline Fitness of driver & 1. & Workers with the following health conditions are not allowed to transport cargo or \\
& $-\quad$ Diabetes \\
& $-\quad$ Degenerative eye condition / eyesight problem \\
& - $\quad$ Forgetful / degrading memory \\
& 2. All vehicle operators shall be regularly tested for drug and alcohol use. \\
& 3. Vehicle operators shall avoid driving when having a sleep problem. \\
& 4. Vehicle operators shall not be allowed to drive when appeared tired. \\
& 5. Vehicle operators with less experience shall not be allowed to travel far distances.
\end{tabular}

Behaviour of driver 1 . Vehicle operators shall always comply to the following safe work procedure when transporting human or / passenger cargo

- Wear seatbelt

- Use safe and familiar route

- $\quad$ Drive with slow speed

- Transport cargo within limit

- $\quad$ No mobile phone use

2. Passengers shall always comply to the following safe work procedure when riding in the oil palm plantations

- $\quad$ Seated in secure seating

- Wear seatbelts

- $\quad$ Remain calm and do not fight during travelling

3. Driver and passengers shall wear appropriate personal protective equipment (PPE) or attire during travelling

4. Vehicle operators or passengers shall perform hazard control or preventive measures when necessary to remove dangers from other road users.

5. Vehicle operators or passengers shall report any commuting hazards / accidents / near-misses to their employer.

6. Vehicle operators or passengers shall report to the authorities if employer failed to provide safe work environment. 


\section{GUIDELINES ON SAFE WORK PRACTICE WHEN COMMUTING IN OIL PALM PLANTATIONS}

\begin{tabular}{|c|c|}
\hline es & $\begin{array}{l}\text { 1. Prior to the use of any vehicles, the following safe work practice should be carried out: } \\
\text { - Basic checks for seat belts, signals, brakes, steering, and tyres } \\
\text { - Tidy and free of grease, mud, and debris } \\
\text { - The seat is adjusted accordingly so all controls are within reach } \\
\text { - Vehicles are made visible to other road users } \\
\text { - Vehicles are well maintained according to the manufacturer's recommendation } \\
\text { - Vehicles are prepared for designated use only (do not misuse for other purposes) } \\
\text { - Vehicles are equipped with a safe operating speed warning } \\
\text { - Vehicles are equipped with firefighting equipment and warning devices for reversing operation } \\
\text { - Vehicles are equipped with working radio communication devices } \\
\text { - For transport of person, the vehicles shall be equipped with the braking system, secure seating and } \\
\text { 2. canopies. } \\
\text { - Vhile in use, the following safe work practice should be carried out: } \\
\text { - Lehicles are driven within the speed limit } \\
\text { - Vehicles are driven within safe routes } \\
\text { - Seat belts are used by drivers and passengers } \\
\text { - No extra person as riders are allowed on loading or cargo } \\
\text { - Never mount or dismount a moving a vehicle } \\
\text { - Vehicles shall only be allowed to move when the operator has clear view in the travelling direction, } \\
\text { 3. } \text { above, and other side, or is in communication with a person who does } \\
\text { - Vehich use, the following safe work practice should be carried out: } \\
\text { - Engage parking brake before dismounting a vehicle } \\
\text { - Starter keys are removed when the vehicle is unattended } \\
\text { - Vehicles are cleaned from grease, mud, and debris } \\
\text { - Any mechanical issue is reported to the supervisor or employer } \\
\text { - Problematic vehicles shall be labelled and not allowed to be used until a proper repair }\end{array}$ \\
\hline Environment & $\begin{array}{l}\text { 1. Commuting or travelling during the following conditions are advised to be postponed or cancelled: } \\
\text { - Heavy rain } \\
\text { - Storm } \\
\text { - Lightning } \\
\text { - Heavy haze } \\
\text { 2. Commuting or travelling in the following conditions shall be done with extra care and slower speed: } \\
\text { - Slippery road due to rain or pool of water } \\
\text { - Muddy routes } \\
\text { - Uneven road (hills, slopes, and stones) } \\
\text { - Nearby valley or ravine }\end{array}$ \\
\hline
\end{tabular}




\begin{tabular}{|c|c|c|}
\hline $\begin{array}{c}\text { Employer's } \\
\text { commitment to } \\
\text { safety issue and } \\
\text { legal duties }\end{array}$ & 1. & $\begin{array}{l}\text { The employer shall provide and make available the following items to all employees in ensuring the } \\
\text { safety of workers } \\
\text { - Safe work procedure as guidelines } \\
\text { - Personal protective equipment (PPE) } \\
\text { - Warning signages at all dangerous areas } \\
\text { - Safe access and egress for all types of vehicles used in the plantation } \\
\text { - Proper lighting equipment for morning use or in difficult weather condition } \\
\text { - Update on hazards along the route } \\
\text { The employer is also advised to perform the following items regularly } \\
\text { - Road / route inspection } \\
\text { - Housekeeping } \\
\text { - Scheduled vehicle maintenance } \\
\text { - Consultation with employees regarding safety issues } \\
\text { The employer shall enforce the following matters to increase safety performance in the oil palm } \\
\text { plantations } \\
\text { - Specialised comprehensive training according to the type of vehicle } \\
\text { - Frequent supervision } \\
\text { - Hazard and safety reporting } \\
\text { - Removal of workers who repeatedly failed to comply with safety rules or safe work procedures }\end{array}$ \\
\hline $\begin{array}{c}\text { Comprehensive } \\
\text { Farm Vehicular } \\
\text { Training }\end{array}$ & & $\begin{array}{l}\text { All vehicle operators shall attend regular training to ensure their knowledge of safe operating are up to } \\
\text { date } \\
\text { The safety training provided must be designed according to the type of vehicles } \\
\text { The training class shall be separated according to type of vehicle and attended by its designated } \\
\text { operators } \\
\text { Employees shall always be reminded to commute safely during safety briefing prior to start of work }\end{array}$ \\
\hline
\end{tabular}

\section{DISCUSSION}

With the literature used in this paper, we found six contributing factors to commuting accidents. Though all the factors were originally from studies in other industries, factors that are relevant to commuting in the oil palm plantations were included. Most of the studies that we reviewed discussed the commuting accidents on the road, while our study setting was the oil palm plantation which usually located at a remote location, within the thick oil palm tree forest, prone to having poor road condition, vast, and bushy. Therefore, the risk and hazard in our study were more threatening than those on the regular road. Having said that, we recognised that our study is a surface study which requires further and detail field investigation at the oil palm plantations to identify more risk and hazard.

Despite that, the contributing factors that we collected from this review shall not be ignored. Some of the factors were discussed in previous commuting accident studies but their elaborations were not clear such as the health status of the driver and employers' commitment. In this study, we collected more information on the health status of the driver which may affect their driving skills. In previous studies on safe commuting, health factors usually include age, sleep quality, fatigue, and stress factors. However, there were illnesses such as diabetes, cognitive failures, recently or frequently undergone the Magnetic Resonance Imaging (MRI) scan that can also affect safe commuting. These illnesses apparently have acute effects like dizziness, drowsiness, loss of focus and balance, and hence decrease someone's safety performance. We also gathered safety commitment which shall be performed by the employer to improve safe commuting in their workplace. Other than that, we included lighting issue and vehicle visibility in the contributing factor.

The guidelines on safety and health that we referred to in developing our safe work practice were detailed and thoroughly written. Even so, the guidelines were designed to cover a variety of farm ranges in the agriculture sector. The sentences are long and may not be of interest of those in lower rankings in the farm. Therefore, we intended to provide a safe work practice guideline which is easier to be referred and more suitable for safe commuting in the oil palm plantations. Then again, our guidelines were based on the review of previous literature on the contributing factors to commuting accidents, thus, the proposed safe work practices were inconclusive and require improvement.

\section{CONCLUSION}

This study presents six main factors that may contribute to the commuting accidents in the oil palm plantations namely health condition, as well as the behaviour of driver, environment, vehicles, employers' commitment, and training. Safe work practice guidelines were proposed according to these factors and crossreferred with the guidelines on safety and health in agriculture published by ILO and DOSH. Since this study is based on the reviews of other commuting accident studies, our suggestions on the safe work practice are limited and inconclusive, hence further study in the oil palm plantation is recommended. Nonetheless, the 
proposed guidelines can be a basic safe work practice which any organisation can refer to in order to improve safe commuting in their workplace.

\section{REFERENCES}

1. Department of Statistics Malaysia (DOSM), Selected agricultural indicators, Malaysia, 2017. Available: https://www.dosm.gov.my/v1/index.php?r=column/pdfPre v\&id=MDNYUitINmRKcENRY2FvMmR5TWdGdz09.

2. Malaysia Productivity Corporation (MPC), Productivity report 2016/2017. 2017, Available: http://www.mpc.gov.my/wpcontent/uploads/2017/05/Productivity-Report-2017.pdf.

3. Malaysian Palm Oil Board (MPOB), Overview of the Malaysian oil palm industry 2017. Available: http://bepi.mpob.gov.my/images/overview/Overview_of_I ndustry_2017.pdf.

4. M. M. Mokhtar, B. M. Deros, and E. H. Sukadarin, "Evaluation of musculoskeletal disorders prevalence during oil palm fresh fruit bunches harvesting using RULA," Advanced Engineering Forum, 10, 2013, pp. 110-115.

5. N. S. Nawi, B. M. Deros, M. N. Rahman, E. H. Sukadarin, and N. Nordin, "Malaysian oil palm workers are in pain: Hazards identification and ergonomics related problems," Malaysian Journal of Public Health Medicine, 16, 2016, pp. 50-57.

6. Y. G. Ng, M. T. Bahri, M. Y. Syah, I. Mori, and Z. Hashim, "Ergonomics observation: Harvesting tasks at oil palm plantation," Journal of Occupational Health, 55(5), 2013, pp. 405-414.

7. Y. G. Ng, S. B. Tamrin, W. M. Yik, I. S. Yusoff, and I. Mori, "The prevalence of musculoskeletal disorder and association with productivity loss: A preliminary study among labour intensive manual harvesting activities in oil palm plantation," Industrial Health, 52(1), 2014, pp. 78-85.

8. E. H. Sukadarin, B. M. Deros, J. A. Ghani, A. R. Ismail, M. M. Mokhtar, and D. Mohamad, "Investigation of ergonomics risk factors for musculoskeletal disorders among oil palm workers using Quick Exposure Check (QEC)," Advanced Engineering Forum, 10, 2013, pp. 103109.

9. A. Sulong, A. Hassan, and T. Hussin, "Workplace accidents and underreporting among the oil palm workers: A pilot study," Science International (Lahore), 30(3), 2018, pp. 479-483.

10. M. N. Selamat, and L. Surienty, "An examination of commuting accident in Malaysia," 3rd Scientific Conference on Occupational Safety and Health, 2015, pp. 171-178.

11. Department of Occupational Safety and Health., Fatal accident case. 2018, Available: http://www.dosh.gov.my/index.php/en/fatal-accident-case.

12. V. V. Khanzode, J. Maiti, and P. K. Ray, "Occupational injury and accident research: A comprehensive review," Safety Science, 50(5), 2012, pp. 1355-1367.

13. N. H. A. Aziz, "The employer's duties and liabilities in commuting accidents in Malaysia: Law and management," Procedia-Social and Behavioral Sciences, 211, 2015, pp. 796-802.

14. E. S. Sukor, A. Suratkon, H. Mohammad H, and S. K. Yaman, "Safe commuting factors from existing guidelines in Malaysia: A review for the construction sector," IOP Conference Series: Earth and Environmental Science, 140(1), 2018, pp. 1-9.

15. S. S. Yaacob, K. I. Ismail, S. Z. Shaarial, N. M. Noor, R. Selvaraju, and H. A. Ghani, "Commuting accidents among health care workers working in Malaysia government hospitals," KnE Life Sciences, 4(5), 2018, pp. 79-87.
16. O. Lykhova, O. Kovalova, N. Bezdenezhnykh, I Adamenko, A. Vorontsova, L. Strokovska, and Y. Kudryavets, "Inhibition of malignant potential and expression of proteins associated with epithelialmesenchymal transition in Lewis lung carcinoma cells transduced with murine ifn- $\beta$ gene in recombinant baculovirus," Experimental Oncology, 38(1), 2016, pp. 13 21.

17. T. Spiegel, O. Rubin, and N. Steverink, "Having both hands on the steering wheel: Driving behaviour of whitecollar workers with degenerative eye conditions," Transportation Research Part F: Traffic Psychology and Behaviour, 44, 2017, pp. 1-11.

18. M. A. Camino López, Ó. J. González Alcántara, and I. Fontaneda, "Gender differences in commuting injuries in Spain and their impact on injury prevention," BioMed Research International, 2017, 2017, pp. 1-11.

19. J. Brière, and S. Smailili, Main results and prospects. 2014, Available:

http://invs.santepubliquefrance.fr/content/download/91667/ 334078/version/1/file/plaque.

20. A. Elfering, S. Grebner, and F. D. T. Hardy, "The long arm of time pressure at work: Cognitive failure and commuting near-accidents," European Journal of Work and Organizational Psychology, 22(6), 2013, pp. 737-749.

21. A. Huss, K. Schaap, and H. Kromhout, "MRI-related magnetic field exposures and risk of commuting accidentsA cross-sectional survey among Dutch imaging technicians," Environmental Research, 156, 2017, pp. 613618.

22. Bongers S, P. Slottje, L. Portengen, and H. Kromhout, "Exposure to static magnetic fields and risk of accidents among a cohort of workers from a medical imaging device manufacturing facility," Magnetic Resonance in Medicine, 75(5), 2016, pp. 2165-2174.

23. D. Pereira, S. Bucher, and A. Elfering, "Daily impaired detachment and short-term effects of impaired sleep quality on next-day commuting near-accidents-An ambulatory diary study," Ergonomics, 59(8), 2016, pp. 1121-1131.

24. B. Barlas, and F. B. Izci, "Individual and workplace factors related to fatal occupational accidents among shipyard workers in Turkey," Safety Science, 101, 2018, pp. 173179.

25. F. Valent, M. Mariuz, G. Liva, F. Bellomo, D. De Corti, S. Degan, A. Ferrazzano, and S. Brusaferro, "A casecrossover study of sleep, fatigue, and other transient exposures at workplace and the risk of non-fatal occupational injuries among the employees of an Italian academic hospital," International Journal of Occupational Medicine and Environmental Health, 29(6), 2016. pp. 1001-1009.

26. Department of Occupational Safety and Health, Guidelines on Occupational Safety and Health in Agriculture. Available: http://www.niosh.com.my/publication/list-ofpublic/152-guidelines-on-occupational-safety-and-healthin-agriculture-dosh-2003, 2013.

27. A. Messineo, M. Cattaruzza, C. Prestigiacomo, F. Giordano, and L. T. Marsella, "Sustainability of prevention practices at the workplace: Safety, simplification, productivity and effectiveness," Annali Di Igiene Medicina Preventiva E Di Comunità, 29(1), 2017, pp. 1-5.

28. A. Muttray, A. Breitinger, E. Goetze, T. Schnupp, B. Geissler, T. Kaufmann, M. Golz, and S. Letzel, "Further development of a commercial driving simulation for research in occupational medicine," International Journal of Occupational Medicine and Environmental Health, 6, 2013, pp. 949-965. 
29. International Labour Organization, Safety and Health in Agriculture. Geneva: International Labour Office, 2011.

30. M. K. Ibrahim, A. A Rashid, M. F. Siam, and L. S. Fin, Hazard profiling of courier riders' delivery route. Research report, Selangor: Malaysian Institute of Road Safety Research (MIROS), 2017.

31. K. K. Harland, M. Greenan, and M. Ramirez, "Not just a rural occurrence: Differences in agricultural equipment crash characteristics by rural-urban crash site and proximity to town," Accident Analysis and Prevention, 70, 2014, pp. 8-13.

32. M. Aldulaimi, and L. A. Jimenez, " 759 Road lighting and safety: A pilot study of Arthabaska region," Injury Prevention, 22(Suppl 2), 2016, pp. A272.

33. N. R. Bin, "Rising trend of work-related commuting accidents, deaths, injuries and disabilities in developing countries: A case study of Malaysia," Industrial Health, 52(4), 2014, pp. 275-277. 